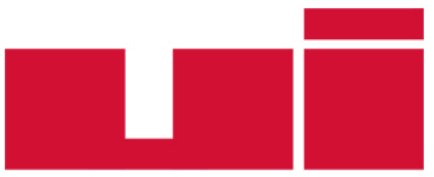

$\underset{\substack{\text { ULLUSLARARASSilisişKiLER } \\ \text { Akademik Dergi }}}{\text { D. }}$

Yayın ilkeleri, izinler ve abonelik hakkında ayrıntılı bilgi:

E-mail: bilgi@uidergisi.com

Web: www.uidergisi.com

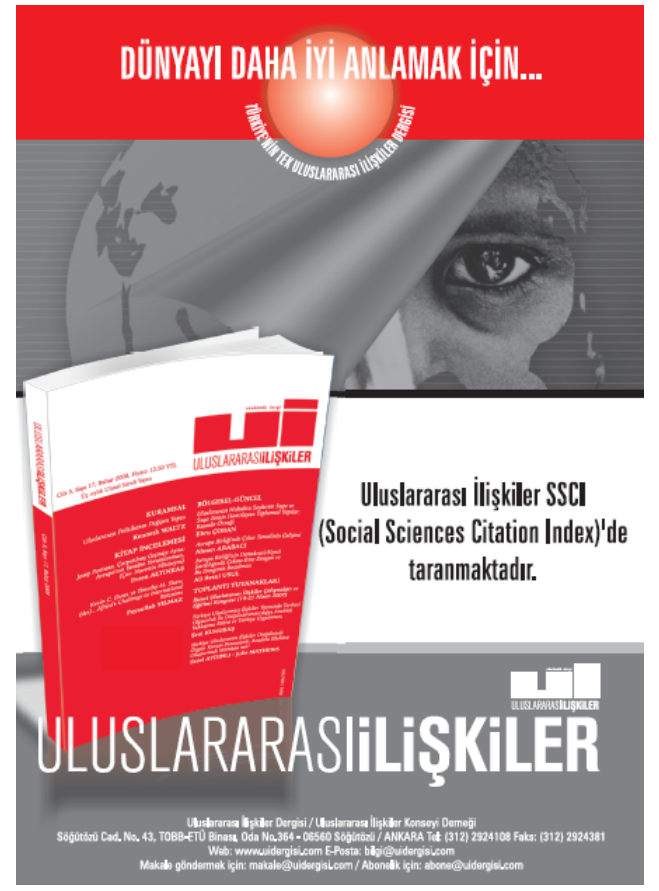

\title{
Rus Dış Enerji Politikası ve Yeni Hedef Kuzey Doğu Asya
}

\section{Tuğçe VAROL SEVİM*}

* Dr., Moskova Devlet Üniversitesi, Küresel Süreçler Fakültesi

Bu makaleye atıf için: Varol Sevim, Tuğçe, "Rus Dış Enerji Politikası ve Yeni Hedef Kuzey Doğu Asya", Uluslararası İlişkiler, Cilt 11, Sayı 41 (Bahar 2014), s. 87-108.

Bu makalenin tüm hakları Uluslararası İlișkiler Konseyi Derneği'ne aittir. Önceden yazılı izin alınmadan hiç bir iletişim, kopyalama ya da yayın sistemi kullanılarak yeniden yayımlanamaz, çoğaltılamaz, dağıtılamaz, satılamaz veya herhangi bir şekilde kamunun ücretli/ücretsiz kullanımına sunulamaz. Akademik ve haber amaçlı kısa alıntılar bu kuralın dışındadır.

Aksi belirtilmediği sürece Uluslararası Illişkiler'de yayınlanan yazılarda belirtilen fikirler yalnızca yazarına/yazarlarına aittir. UIKK Derneğini, editörleri ve diğer yazarları bağlamaz. 


\title{
Rus Dış Enerji Politikası ve Yeni Hedef Kuzey Doğu Asya
}

\author{
Tuğçe VAROL SEVİ**
}

\section{ÖZET}

Zengin enerji kaynakları ve bu enerji kaynaklarının ekonomisindeki yeri nedeniyle Rusya Federasyonu dünya enerji pazarının en önemli oyuncularından birisidir. Rus dış enerji politikası, ülkenin büyümesini ve yumuşak hegemonik gücün bir kez daha Orta Asya'da sürdürülebilmesi için yeni enerji pazarlarına ihtiyaç duymaktadır. Bu bağlamda Doğu Asya’da Çin, Rusya'nın bölgeye geri dönmesi karşısında en büyük tüketici ve rekabetçisi olarak ortaya çıkmaktadır. Ancak Çin, üç Orta Asya devleti ile ekonomik ve enerji ilişkilerini geliştirmeyi başarmış ve bölgede denge oluşmasına katkıda bulunmuştur. Buna karşılık, Rusya ise Rus-Çin doğal gaz görüşmeleri olmasına rağmen yüzünü Japonyałya çevirerek Pekin ve Tokyo ile Pekin ve Seul arasındaki Rus enerji kaynakları için rekabeti tetiklemeye çalışmıştır. Bu nedenle bu çalışma da Rusya'nın üç küresel aktör olan Çin, Japonya ve iki Kore'ye bakarak Doğu Asya'ya yönelik yeni dış enerji politikası incelenmesi hedeflenmektedir.

Anahtar Kelimeler: Rus Dış Politikası, Enerji Politikaları, Enerji Güvenliği, Çin, Kuzey Doğu Asya.

\section{Russian External Energy Policy and North East Asia as its New Target}

\begin{abstract}
Russia is one of the major players of the world energy market due to its vast resources and places of energy resources in its economy. Russian foreign energy policy needs new markets in order to sustain its growth and soft hegemony once more in Central Asia. In East Asia, China remains to be great consumer and a competitor for Russian great turning back to the region. However China has improved its economic and energy relations with particular three Central Asian states, and constituted a balance in the region in terms of Russian energy monopoly perspective. In return, Russia turned its face to Japan in order to trigger a competition between Beijing and Tokyo and/or Seoul for Russian energy resources despite the ongoing RussianChinese natural gas price talks. For that reason, it is aimed to analyze of Russian new foreign energy policy towards Asia regarding three global actors; China, Japan and the two Koreas.
\end{abstract}

Keywords: Russian Foreign Policy, Energy Politics, Energy Security, China, North East Asia.

* Dr. Küresel Süreçler Fakültesi, Moskova Devlet Üniversitesi, Moskova, Rusya Federasyonu. TÜBİTAK 2219 Doktora Sonrası Araştırma Bursiyeri, 2013-2014. E-posta: tugcevarol@ hotmail.com. 


\section{Giriş}

Rusya Federasyonu'nun 1991'de bağımsızlı̆̆ını kazanmasından itibaren, Rusya dış politikası ve iktisadi yapısını birleştirecek bir dış enerji politikası takip etmektedir. 2000 yılında Vladimir Putin'in Rusya Başkanı olmasıyla birlikte, enerji sektörü en öncelikli ekonomik sektör statüsüne yükseltilmiş ve bunun ülkenin yeniden süper güç olmasında kuşkusuz en önemli katkısının olacağı kararlaştırılmışır. ${ }^{1}$ Rusya, zengin hidrokarbon rezervlerine sahip olmakla birlikte bunun bir sonucu olarak da ekonomisi petrol ve doğal gaz fiyatlarının iniş çıkışları nedeniyle bir o kadar kırılgandır. Dolayısıyla Rusya'nın yüksek doğal gaz gelirlerini garanti edebilmek adına alıcı ülkeler ile uzun dönemli kontratlar, yeni boru hatları ve yeni dönemde işlevsel bir LNG (Likit Doğal Gaz) sektörü kurmaya ihtiyacı bulunmaktadır. Mevcut durumda Avrupa pazarı Rusya'nın doğal gaz üretimine büyük miktarda bağlanmış ve yeni boru hattı projeleri inşa edilmek üzere ilişkiler güçlendirilmiş veya en azından süreç Kremlin'in istediği gibi tasarlanabilmiştir. Fakat bu durum bir yandan Avrupa'nın Rusya'ya bağımlılı̆̆ını ortaya çıkartırken diğer yandan da Rusya’yı Avrupa pazarına bağımlı hale getirmiştir. Bu nedenle Rusya'nın alternatif olarak boru hatları ve uzun dönemli kontratlar ile kurabileceği bir diğer pazar olarak da Uzak Doğu'da Çin, Japonya ve iki Kore belirmiştir.

Bu ülkeler arasında Çin'in giderek artan enerji talebi nedeniyle, Kremlin açısından bölgenin fethedilmesi gereken kalesi anlamını taşımaktadır. Diğer yandan Japonya ve iki Kore'nin enerji talebi Rusya açısından önemli olsa da, esas itibariyle bu iki ülke Çin'in enerji ihtiyaçlarını tedarik edebilme stratejisinde masada yer alan iki kart olma özelliği taşımaktadırlar. Japonya ve Güney Kore iki endüstrileşmiş ülke olarak acilen enerji ithalat yollarını çeşitlendirme ihtiyacını hissetmektedirler. Çin'in enerji ihtiyacındaki artış ise Japonya ve iki Kore'ye kıyasla çok daha yüksektir. Bu nokta da Rusya, Japonya ve iki Kore ile birlikte bir üçgen oluşturarak on yıldan fazla süredir Çin hükümeti ile sürdürdüğü Çin'in Rusya'dan alacağı doğal gazın fiyatına ilişkin görüşmeleri etkilemeye çalışmaktadır. Nihayetinde Japonya ile gerçekleştirilen LNG anlaşması ve iki Kore ile yürütülen TransKore boru hattı projesi görüşmeleri Çin’in Rusya ile uzun dönemli petrol ve doğal gaz anlaşmaları imzalamasına neden olmuştur.

\section{Enerji Odaklı Rus Ekonomisi}

1991 yllında Sovyetler Birliğinnin dağılmasının ardından merkezi bir ekonomik sistemi terk eden mirasçı ülke Rusya Federasyonu için yeni geçiş dönemi ekonomisi süreci başlamıştır. Geçiş döneminin ilk aşaması olarak kabul edilen 1991-1998 döneminde Rusya’nın GSMH'si yüzde 30 oranında düşmüş ve çok yüksek enflasyonun söz konusu olduğu bir dönem yaşanmıştır. ${ }^{2} 1999$ yılının ikinci yarısından itibaren ise rublenin değer kaybetme-

1 Anita Orban, Power, Energy and the New Russian Imperialism, Praeger Security International Press, 2008, s.11.

2 William H. Cooper, "Russia's Economic Performance and Policies and Their Implications for the United States," CRS Report For Congress, Order Code RL34512, 30 May1s 2008, s.3, http:// www.fas.org/sgp/crs/row/RL34512.pdf (Erişim Tarihi 22 Nisan 2013). 
sine ilave olarak Rus ekonomisi petrol fiyatlarındaki artı̧̧ nedeniyle ekonomisine likit para sağlayarak göreceli de olsa bir düzelme belirtisi göstermeye başlamıştır. ${ }^{3}$ Svetsova’ya göre de bu dönemde ekonomide başarı sağlanmasının en temel nedeni yüksek petrol fiyatları ve ülke içerisinde yabancı rekabetine kapalı kalan stratejik endüstri ve ticaret alanlarının korunmasıdır. ${ }^{4}$ Vladimir Putin'in ilk sekiz yıllık başkanlık döneminde Rusya'da GSMH 1998-2008 arasında ortalama yüzde 6,94 oranında büyüme kaydetmiştir. Bush'a göre de böylesi bir başarının kaydedilmesinin sebebi sadece petrol fiyatlarının yükselmesi değil, doğal gaz fiyatlarının da bununla bağlantılı olarak yükselmesi ve 1998 Ağustos'unda yaşanan devalüasyonun olumlu etkilerinin 2000'lerin ilk on y1lında görülmesidir. ${ }^{5}$

2010 yılının ortasında Rusya, dünyanın en büyük doğal gaz rezervlerine sahip olmasının yanı sıra Suudi Arabistan' $1^{6}$ geride bırakarak dünyanın günde en fazla petrol üreten ülkesi konumuna yükselmiştir. Rusya'nın modern tarihi boyunca siyasi ekonomisi, doğal kaynaklardan elde edilen gelirlerin ekonominin diğer sektörlerine aktarılması şeklinde bir yaklaşım izlemiştir. ${ }^{7}$ Bu bağlamda petrol ve doğal gaz fiyatlarının Rus ekonomisine etkisini gösteren çeşitli çalışmalara bakmak gerekmektedir. Beck, Kamps ve Mileva'nın çalışmalarına göre petrol fiyatlarındaki yüzde 10 oranındaki bir artış, Rus GSMH'sinin yüzde 1,5-2 oranında büyümesini sağlamaktadır. ${ }^{8}$ Diğer yandan Cukrowski ise petrol fiyatlarındaki yüzde 10 civarındaki uzun dönemli bir artı̧̧ ya da azalmanın yine Rus GSMH'sinin yüzde 2,2 büyümesine ya da küçülmesine sebep olabileceğini iddia etmektedir. ${ }^{9}$ Rus ekonomisinin 21. yüzyılın ilk on y1lında petrol ve doğal gaz ihracatından nasıl gelir sağladığını göstermek açısından Rusya Federasyonu Merkez Bankası'nın her üç ayda bir yayınladığ 1 rakamlara bakmak faydalı olacaktır. Tablo 1'de görüldüğü üzere petrol fiyatları 2000 yılında ancak 24 dolar civarındayken 2012 y1lı ortalama 103 dolarda tamamlamıştır. Rusya’nın petrolden her yıl sağladığı yükselen gelirini kıyaslamak açısından 2000 yılında 25 milyar dolar olan gelirin 2012 yılında 180 milyar dolar seviyesine geldiği görülmektedir. Bu rakamda gelirdeki artışın yüzde 720 olduğunu ifade etmektedir. Aynı durum doğal gaz içinde söz konusu olup Rusya'nın 2000 yılından 2012 yılına kadar doğal

3 Jouko Raotava, "The Role of Oil Prices and the Real Exchange Rate in Russia's Economy", BOFIT Discussions Papers, No 3, 2002, s.7.

4 Lilia Shevtsova, "Post-Communist Russia: A Historic Opportunity Missed", International Affairs, Cilt 83, No 5, 2007, s.895.

5 Keith Bush, "Russian Economic Survey”, US-Russia Business Council, Aralık 2008, s.5 https:// www.usrbc.org/ (Erişim Tarihi 19 Mayıs 2013); Evgeny Gavrilenkov, "Growth in Russia and Economic Diversification”, Tabata Shinichiro ve Akihiro Iwashita (der.), Slavic Eurasia's Integration into the World Economy and Community, Slavic Eurasian Studies, No.2, Sapporo, Japonya, 2004, s.96.

6 "Russia Becomes Leading Oil Producer, BP Says", BBC News, 9 Haziran 2010, http://www. bbc.co.uk/news/10275183 (Erişim Tarihi 10 Mayıs 2013).

7 Clifford G. Gaddy ve Barry W. Ickes, "Resource Rents and the Russian Economy”, Eurasian Geography and Economics, Cilt 46, No 8, 2005, s.559.

8 Roland Beck, Annette Kamps ve Elitza Mileva, "Long-Term Growth Prospects For the Russian Economy”, European Central Bank, Occasional Paper, No 58, Mart 2007, s.9.

9 Jacek Cukrowski, "Russian Oil: The Role of the Sector in Russia's Economy", Post-Communist Economies, Cilt 16, No 3, 2004, s.286. 
gaz ihracatından sağladığı geliri yaklaşık yüzde 380 oranında artmıştır. Yine Rusya'nın 2009 yılında başlattığı LNG ihracatı da dört yıl içerisinde yüzde 560 oranında artan bir gelir sağlamıştır.

Tablo 1: Rusya'nın Seçilen Yillar İçin Petrol İhracat Rakamlar110

\begin{tabular}{|c|c|c|c|}
\hline Y11 & Toplam (m/t) & $\begin{array}{c}\text { Değer Milyon Dolar } \\
\text { USD }\end{array}$ & $\begin{array}{c}\text { İhracat Ortalama } \\
\text { Fiyatı USD/bbl }^{11}\end{array}$ \\
\hline 2000 & 144,4 & 25271,9 & 23,94 \\
\hline 2005 & 252,5 & 83438 & 45,21 \\
\hline 2010 & 250,7 & 135799,3 & 74,11 \\
\hline 2011 & 244,5 & 181812,4 & 101,74 \\
\hline 2012 & 239,9 & 180915,9 & 103,14 \\
\hline
\end{tabular}

Tablo 2: Rusya'nın Seçilen Yıllar İçin Doğal Gaz İhracat Rakamları ${ }^{12}$

\begin{tabular}{|c|c|c|c|}
\hline Yil & $\begin{array}{c}\text { Toplam } \\
\left(\text { Milyar m }^{3}\right)^{13}\end{array}$ & $\begin{array}{c}\text { Değer Milyon Dolar } \\
\text { USD }\end{array}$ & $\begin{array}{c}\text { İhracat Ortalama } \\
\text { Fiyatı USD/1000 m }\end{array}$ \\
\hline 2000 & 193,9 & 16644,1 & 85,84 \\
\hline 2006 & 202,8 & 43806,2 & 216 \\
\hline 2010 & 177,8 & 47739,3 & 268,48 \\
\hline 2011 & 189,7 & 64290,1 & 338,88 \\
\hline 2012 & 178,7 & 62986,7 & 352,56 \\
\hline
\end{tabular}

Tablo 3: LNG İhracat Rakamları 2009-201214

\begin{tabular}{|c|c|c|c|}
\hline Yll & $\begin{array}{c}\text { Toplam } \\
\left(\text { Milyar } \mathbf{m}^{3}\right)\end{array}$ & $\begin{array}{l}\text { Değer Milyon } \\
\text { Dolar USD }\end{array}$ & $\begin{array}{c}\text { İhracat Ortalama Fiyatı } \\
\text { USD } / \mathbf{m}^{3}\end{array}$ \\
\hline 2009 & 8,4 & 835,8 & 99,53 \\
\hline 2010 & 24 & 2986,7 & 124,24 \\
\hline 2011 & 22,8 & 3854,5 & 168,79 \\
\hline 2012 & 21,4 & 4679,1 & 218,45 \\
\hline
\end{tabular}

10 Export of Russian Crude Oil for 2000-2012, Russian Federal Customs Service and the Federal State Statistics Service,http://www.cbr.ru/eng/statistics/print.aspx?file=credit_statistics/crude_ oil_e.htm\&pid=svs\&sid=vt1(Erişim Tarihi 10 Mayıs 2013).

11 Varil.

12 Exports of Russian Natural Gas For 2000-2012, Russian Federal Customs Service and the Federal State Statistics Service, http://www.cbr.ru/statistics/print.aspx?file=credit_statistics/ gas.htm (Erişim Tarihi 10 Mayıs 2013)

13 Milyar metre küp.

14 Russian Federation: Liquefied Natural Gas Exports, 2009-2012, Russian Federal Customs Service and the Federal State Statistics Service, http://www.cbr.ru/eng/statistics/print. aspx?file=credit_statistics/Liquefied-Gas_e.htm\&pid=svs\&sid=ITM_7686 (Erişim Tarihi 10 Mayıs 2013) 
IMF'nin yaptığ nındadır. Fakat petrolden elde edilen gelirler bütçe hesabının dışında bırakılırsa GSMH'deki artışın yüzde 3,4 olduğu görülmektedir. ${ }^{2}$ Başkan Putin'in de söylediği gibi "en azından bugün dünya ekonomisinin ilerlemesindeki en önemli güç motifi enerjidir. Bugün ve gelecekteki Rusya'nın refahı direkt olarak bizim, küresel enerji bağlamında bulunacağımız yere bağlıdır." ${ }^{15}$ Başkan Putin tarafından özellikle üzerinde titizlikle durulan bir başka konu da uzun dönemli doğal gaz sözleşmelerinin imzalanmasıdır. Rusya'nın Avrupa ve Orta Asya boru hatları hariç henüz Doğu Asya'ya ulaşmış aktif bir doğal gaz boru hattı bulunmamakta fakat inşa halinde olan ve görüşmeleri süren projeleri bulunmaktadır. Doğal gaz sektöründeki istikrar sadece ihracat gelirleri için değil aynı zamanda ülkenin kendi doğal gaz ihtiyacını kesintisiz sağlamak için de önem arz etmektedir. Doğal gazın Rus ekonomisindeki etkisi kısmi olarak petrolden daha farklıdır çünkü doğal gaz konusunda OPEC gibi bağlayıcı bir uluslararası örgüt bulunmamaktadır. Dolayısıyla, Rusya ihraç edeceği doğal gazın fiyatını belirlemekte neredeyse tamamen özgürdür. Bu sebepten ötürü de geçtiğimiz on y1l içerisinde doğal gazdan çok büyük gelirler elde etmiştir. Fakat son yıllarda Avrupa Birliği içerisinde gerçekleşen ve hukuki süreçlerle devam eden Rus gazının fiyatındaki itirazlar nedeniyle Rusya, az da olsa fiyat indirimine gitmek zorunda kalmıştır.

\section{Rus Diş Enerji Politikası}

Rusya Federasyonun bağımsızlı̆̆ını kazandığı günden itibaren ekonomisinde enerji kaynakları ihracat rakamlarının oluşturduğu yüksek oran nedeniyle bütünleşik ve resmi olarak tanımladığ1 "Dış Enerji Politikası” önemli bir kavram teşkil etmektedir. 2000 yılı ise Vladimir Putin’in Rusya Başkanlığına seçilmesi ve Vladimir Putin’in aktif bir şekilde ülkenin dış politikası ve enerji stratejisini tasarlaması nedeniyle bir dönüm noktasıdır. Başkan Putin'e göre Rusya eğer ekonomik ve sosyal anlamda gelişemezse tekrar bir süper güç olma ihtimali olmadığ 1 gibi dünya tarihinden de kaybolmaya mahkûmdur. ${ }^{16}$ Dolayısıyla Başkan Putin Rus dış politikası ve enerji politikasını adeta iç içe geçirerek Rus ulusal çıkarı için enerji kartını gerektiğinde kullanmaya başlamıştır. Vladimir Putin’in birinci başkanlık döneminde Rus ekonomisi kuşkusuz yüksek petrol ve doğal gaz fiyatlarından olumlu yönde etkilenmiştir. Fakat bu durum Rus ekonomisini bir tarafta enerji hammaddesinin ihracatına ve boru hatlarının inşa edilmesine bağımlı hale getirirken diğer yanda da enerji ihracatından elde ettiği sıcak paraya bağımlı hale gelmiştir. ${ }^{17}$

15 Robert Legvold, "Russia's Strategic Vision and the Role of the Energy", NBR Analysis, Russian Energy Policy and Strategy, Cilt 1, No 2, 2008, s.14.

16 Anita Orban, Power, Energy and the New Russian Imperialism, s.11.

17 Fiona Hill, Energy Empire: Oil, Gas and Russia's Revival, The Foreign Policy Centre, Eylül, s.57. 
Doğal kaynakların nasıl kullanılacağına ve bu kaynaklardan ülkenin dış enerji politikası oluşturulurken nasıl faydalanacağına dair bir doktora tezi ${ }^{18}$ olan Vladimir $\mathrm{Pu}-$ tin, kuşkusuz resmi "dış enerji politikasının” yazılımında da etkili olmuştur. Bu bağlamda Rusya, dünya da resmi olarak "dış enerji politikası” olan tek ülkedir. Söz konusu politika Rusya'nın Enerji Stratejisi Dokümanında şu şekilde açılanmaktadır:

Dış enerji politikasının stratejik amacı, Rusya'nın enerji potansiyelini dünya pazarlarına tam olarak entegre olabilmesi için maksimum etkin derecede kullanmak, onun üzerine pozisyonları arttırmak ve ulusal ekonomi için en yüksek ihtimalli karı kazanmaktır. ${ }^{19}$

Rus Merkezi Bankası bilgilerine göre Rusya, 2011 yılında $244,5 \mathrm{~m} / \mathrm{t}^{20}$ ve 2012 yılında da $239,9 \mathrm{~m} / \mathrm{t}^{21}$ petrol ihraç etmiş ve aynı zamanda dünyanın en büyük petrol üreticisi olmuştur. ${ }^{22}$ Rus petrol ihracatının büyük miktarı (yüzde 78) Avrupa pazarına, yüzde 16’s1 Asya pazarına ve yüzde 6'sı da Kuzey ve Güney Amerika'ya yapılmaktadır. ${ }^{23}$ Doğal gaz alanında ise Rusya’nın doğal gaz ihracatının yüzde 37'si (66 Milyar metreküp -2012) Bağımsız Devletler Topluluğu ülkelerine, yüzde 63’ü (112,6 Milyar metreküp-2012) aralarında Almanya, Türkiye ve İtalya’nın yer aldığ 1 Avrupa ülkelerine yapılmaktadır. ${ }^{24}$ Bunların yanı sıra 2011 yılında Sakhalin adasından Japonya (yüzde 69,5), Güney Kore (yüzde 25,7 ) ve Çin (yüzde 2,4), Tayvan (yüzde 1,7) ve Tayland'a (yüzde 0,6) LNG taşınmıştır. ${ }^{25}$

\section{Yilına Kadar Rus Enerji Stratejisi Belgesi}

2008-2009 krizi her ne kadar az hasarla atlatılmış olsa da ister istemez Rusya'nın petrol üretimi, keşif çalışmaları ve yatırımlarını etkilemiştir. Kriz sırasında hem ülke içi üretimin hem de enerji ihracat rakamlarının düşmesi nedeniyle Rusya’nın planladığı bütçe tahminleri etkilenmiş ve 2020 yllında kadarki dönemi hedefleyen bir önceki Enerji Strateji Belgesi’nin güncellenmesine ihtiyaç duyulmuştur. Rus enerji sektörünün en kısa sürede ayağa kaldırılmasını hedefleyen plan, hükümet tarafından üç aşamalı olarak hazırlanarak 2009 yılında yayınlanmıştır. Kısaca; ilk aşama olan 2013-2015 yılları arasında 2008 krizinin etkilerinin

18 Rusya Başkanı Vladimir Vladimiroviç Putin’ in doktora tezi olup olmadığına dair çeşitli tartışmalar olmakla birlikte, Rusya Federasyonu Başkanlık web sitesinde resmi olarak belirtilen özgeçmişinde St.Petersburg Üniversitesi Madencilik Enstitüsünde 1997 yılında doktora tezini savunduğu belirtilmektedir. Kremlin, http://eng.putin.kremlin.ru/bio (Erişim Tarihi 29 Ocak 2014)

19 Energy Strategy of Russia - For the Period Up To 2030, p.55, http://www.energystrategy.ru/ projects/docs/ES-2030_(Eng).pdf (Erişim Tarihi 14 Eylül 2013)

20 Milyon Ton.

21 Bakınız Tablo 1, 2 ve 3.

22 Jake Rudnitsky, "Russia's 2012 Oil Output Rises to Pos-Soviet Record Prices", Bloomberg, 1 Şubat 2013, http://www.bloomberg.com/news/2013-01-02/russia-s-2012-oil-output-rises-topost-soviet-record-on-prices.html (Erişim Tarihi 3 Mart 2013)

23 EIA-Rusya, 18 Eylül 2012, s.7, http:/www.eia.gov/countries/analysisbriefs/Russia/russia.pdf (Erişim Tarihi 17 Mart 2013)

24 EIA-Rusya, s.1.

25 Ibid, s.17. 
tamamen giderilmesi ve üretimi düşen sahaların yerine yenilerinin aktif hale getirilmesi ile enerji sektörünün modernleştirilmesi hedeflenmektedir. İkinci aşama olan 2015-2022 y1lları arasında ise Rusya'nın Uzak Doğu ve Doğu Sibirya bölgelerinde yeni petrol ve doğal gaz üretim sahalarının oluşturulması hedeflenmektedir. Son olarak 2022-2030 yılları arasında ekonomiye mutlak surette alternatif enerji kaynaklarının da dâhil edilmesi ve ekonomi üzerindeki hidrokarbon ihracatının yarattığı bağımlılığın azaltılması öngörülmektedir. ${ }^{26}$

2030 Enerji Stratejisi belgesinde yer alan bir başka önemli tespit, Avrupa enerji pazarının toplam Rus enerji ihracatındaki oranının göreceli olarak düşürülmesidir. Bunun nedeni Uzak Doğu'daki yeni pazarlar olan Çin, Japonya ve iki Kore'nin önemli ithalatçılar olarak ortaya çıkmasıdır. Buna ilave olarak, belgenin üçüncü aşaması için yapılan tahminlere göre Rus petrolünü ithal edecek olan Doğu pazarının tüm Rus enerji ihracatındaki payının yüzde 6'dan yüzde 22-25'e, doğal gaz ithalatındaki payının da 0'dan yüzde 19-20'a çıkması hedeflenmektedir. ${ }^{27} \mathrm{Bu}$ nedenle Çin, Japonya ve iki Kore, yeni Rus enerji stratejisinin merkezinde yer almaktadırlar. Sonuç olarak Enerji Strateji Belgesi her ne kadar gerçekleştirilmesi zor hedefler öngörüyor olsa da Belge, Rus dış enerji politikası için bir el kitabı niteliği taşımaktadır.

\section{Rusya'nın Kuzey Doğu Asya'ya Yönelik Enerji Stratejisi}

Kremlin'e göre Rusya'nın Uzak Doğu bölgesinin gelişimi ile Kuzey Doğu Asya bölgesi enerji kaynakları, arz ve talep açısından içe içe geçmiş konumdadırlar. Bu nedenle bölgenin ekonomik gelişimi yüksek oranda başta Çin, Japonya ve iki Kore olmak üzere Kuzey Doğu Asya ülkeleri ile kurulacak olan enerji bağına bağlıdır. 2030 yılında, 2000 yılında ABD'nin ithal ettiği miktarda petrolü yani günde 10 milyon varil petrol ithal etmesi beklenen Çin, yükselen enerji arzı talebi nedeniyle bölgenin en önemli aktörüdür. ${ }^{28}$ Diğer yandan Uluslararası Enerji Ajansı'nın (IEA) tahminlerine göre, Çin'in 2010-2030 arası enerji talebindeki yıllık ortalama artış yüzde 2,7 olarak gerçekleşecektir. Yine aynı dönemde Çin'in petrol ihtiyacı dünya ortalamasının tamamının iki katı olarak her yıl ortalama yüzde 3 oranında büyüyecek ve 2030 yilında da günde 12 milyon varil petrol ithal etmek zorunda kalacaktır. ${ }^{29}$

Rusya için ülkenin doğu bölgelerine doğru inşa edilecek boru hatları, Kuzey Doğu Asya enerji pazarına açılabilmek ve bölgeyi geliştirebilmek için en önemli araçlardır. Örneğin Başkan Vladimir Putin, 2002 yılında Ulusal Güvenlik Konseyi’nde yaptığı bir

26 "Russia Adopted New Energy Strategy", Barents Observer, 28 Ağustos 2009, http://www. barentsobserver.com/russia-adopted-new-energy-strategy.4625792-116320.html (Erişim Tarihi 4 Nisan 2013); "Energy Strategy 2030", Russian-American Business, 3 Kasım 2009, http://russianamericanbusiness.org/web_CURRENT/articles/545/1/Energy-strategy-2030 (Erişim Tarihi 4 Nisan 2013).

27 Energy Strategy of Russia For The Period Up To 2030, s.23, http://www.energystrategy.ru/ projects/docs/ES-2030_(Eng).pdf (Erişim Tarihi 01 Nisan 2013).

28 S. Itoh, V.I. Ivanov ve D. Zha, "Chapter VI: China, Japan and Russia: The Energy Nexus", Niklas Swanstöm (der.), Conflict Prevention and Conflict Management in Northeast Asia, 2005, s.122.

29 Ibid., s.124. 
konuşmada Doğu Sibirya petrol boru hattının (ESPO) Rusya'nın Uzak Doğu bölgelerinin çıkarları da düşünülerek yapılmak zorunda olduğunu açıklamıştır. ${ }^{30}$ Ayrıca doğal gaz boru hatları ve LNG sektörünün büyümesi de Rusya’nın Uzak Doğu’su için stratejik önemdedir. Rusya, ülkenin Uzak Doğusundaki Sakhalin adası yakınlarındaki Sakhalin-1 sahasından 9,1 ve Sakhalin projesinden 15,4 olmak üzere 2011 yılında toplam 25,5 milyar metreküp gaz üretmeyi başarmıştır. Yine 2011 yılında Gazprom, Sakhalin adası ile Vladivostok arasındaki sahalarda ilk aşamada yıllık 6 milyar metreküp kapasiteye sahip ilk boru hattını (Sakhalin-Khabarovsk-Vladivostok boru hattı) tamamlamıştır. Boru hattının son aşamasının da tamamlanmasıyla yılda 30 milyar metreküp doğal gazın Kuzey Doğu Asya pazarına taşınması hedeflenmektedir. ${ }^{31}$

\section{Çin}

1985 ve 1995 yılları arasında Çin'in petrol talebi günde 1,7 milyon varilden günde 3,4 milyon varile çıkmıştır. Ardından gelen ilk on yılda ise talep yeniden ikiye katlanarak 6,8 milyon varile ulaşmıştır. ${ }^{32} 1993$ yılına kadar petrol ihraç eden bir ülke olan Çin, hızlı büyüme oranları nedeniyle petrol ithal eden bir ülkeye dönüşmüştür. ${ }^{33} 2009$ y1lında yılda 4,3 milyon varil petrol ithal eden Çin, ABD'nin arkasından ikinci sıraya yerleşmiştir. Uluslararası Enerji Ajansına göre Çin’in ispatlanmış 20,4 milyar varil petrol rezervi bulunmaktadır. ${ }^{34}$ Çin'in 2030 yilına kadar petrol üretiminin de günde 3,4 milyon varile düşeceğini ve petrol ithalatı bağımlılı̆̆ının yüzde 80'e yükseleceği tahmin edilmektedir. ${ }^{35}$

Çin'in Oil and Gas Journala göre 3 trilyon metreküp, Çin devlet şirketi CNPC'ye göre ise 6 trilyon metreküp ispatlanmış gaz rezervi bulunmaktadır. ${ }^{36}$ Çin, artan talep nedeniyle 2007 yılında 20 yılın ardından ilk defa doğal gaz ithal eden bir ülke konumuna

30 Junzo Nakano, "Japan's Security and the Russian Far East, in Sibera and the Russian Far East in the 21st Century: Partners in the 'Community of Asia", Akihiro Iwashita (der.), Cilt 1, Crossroads in Northeast Asia, 2005, s.49.

31 Sergey Sevastyanov, "Russia and Northeast Asia Energy Security", Rouben Azizian ve Artyom Lukin (der.), From APEC 2011 to APEC 2012: American and Russian Perspectives on Asia-Pacific Seucirty and Cooperation, 2012, s.50-51.

32 Xuecheng Liu, "China’s Energy Security and Grand Strategy", The Stanley Foundation, Policy Analysis Brief, Eylül 2006, s.3.

33 Sonja Davidovic, "China's Energy Policy in the Geopolitical Context", Celeste Wallender (der.), Geopolitics of Energy in Eurasia, (MSFS 536), 2008, s.13-14 http://www.atlanticcommunity. org/app/webroot/files/articlepdf/China\%5C's\%20Energy\%20Policy.pdf (Erişim Tarihi 14 Nisan 2013)

34 EIA - Çin, Kasım 2010, s.3 http://www.eia.doe.gov/cabs/China/pdf.pdf (Erişim Tarihi 14 Nisan 2013)

35 Erica S. Downs, "Sino-Russian Energy Relations An Uncertain Courtship”, James Bellacqua (der.), The Future of China-Russia Relations, The University Press of Kentucky, s.148-50, 2010,

36 Nabuyuki Higashi, "Natural Gas in China, Market Evolution and Strategy”, IEA, Working Paper Series, Haziran 2009, s.6. 
gelmiştir. ${ }^{37}$ Diğer yandan Çin’in doğal gaz üretimi de 1980 yllında 14,3 milyar metreküp iken 2006 yllında 58,6 milyar metreküp olarak gerçekleşmiştir. Fakat bu Çin'in ihtiyac1 olan doğal gazı karşılamaya yetmemektedir. Tahminlere göre Çin'in 2020 yılında 130 milyar metreküp gaz ithal etmesi gerekecektir. ${ }^{38}$ Uluslararası Enerji Ajansına göre Çin, kaçınılmaz olarak küresel enerji pazarında belirleyici bir rol oynayacaktır. Ajansın tahminlerine göre 2035 yılında Çin, kendinden sonra ikinci sırada gelecek olan ABD'den yüzde 77 oranında daha fazla enerji tüketen bir ülke olacaktır. ${ }^{39}$

Şekil 1: Çin Enerji Talebi 2030- AB ve ABD Karşılaştırmalı

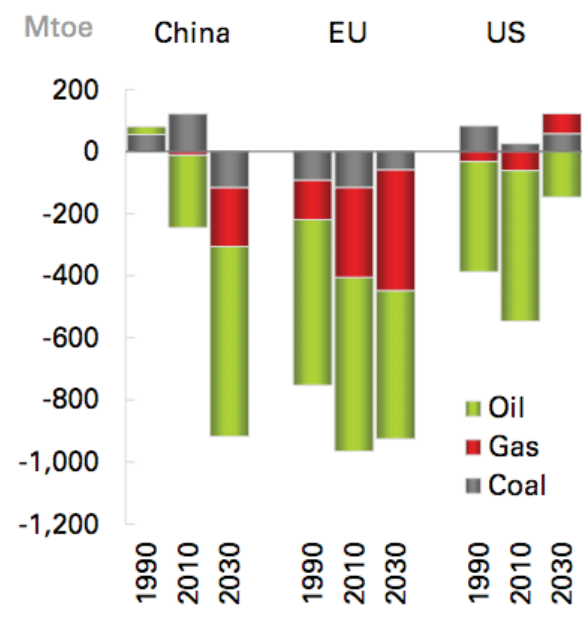

Kaynak: BP Energy Outlook 2030, Ocak 2013, s. 74.

Başkan Putin ve dönemin Çin Devlet Başkanı Zemin arasında Temmuz 2001'de imzalanan İyi Dostluk ve Komşuluk Anlaşması sırasında iki ülke arasında bir petrol hattının inşasını öngören bir anlaşma daha imzalanmıştır. Doğu Sibirya Pasifik Okyanusu (Eastern Siberian Pacific Ocean-ESPO) petrol boru hattı olarak da anılan hattın 2005 yılında öncelikle yılda 20 milyon ton 2010 yılında da 30 milyon ton petrolü taşıması planlanmıştır. ${ }^{40}$ Kısa süre sonra da Rusya'nın petrol boru hatlarından sorumlu devlet şirketi olan Transneft üç aşama ile inşa edilecek olan Rusya'nın Taishet bölgesinden Pasifik okyanusundaki sahiline ulaşacak olan bir hattın yapılacağını açıklamıştır. ${ }^{41}$

37 EIA - Çin, s.11.

38 Davidovic, "China's Energy Policy", s.15-6.

39 “World Energy Outlook 2012”, Uluslararası Enerji Ajans1, s.56

40 Shaichi Itah, “Sino-Russian Energy Relations: True Friendship or Phony Partnership?”, Russian Analytical Digest, No.73, 23 Şubat 2010, s.10.

41 "Russian Government to Approve Pipeline Construction Schedule in 2005", RIA Novosti, 1 Aralık 2005, http://en.ria.ru/russia/20051201/42283689.html (Erişim Tarihi 29 Ocak 2014). 
2003 yılında Japon Başbakanı Koizumi'nin Moskova ziyareti sırasında Japonya'nın projeye destek vereceğini açılamasıyla birlikte Rusya, bu hat için Çin ve Japonya arasında bir rekabet başlatmıştır. Çin'in Rusya'ya yatırım yapma aşamalarındaki gecikmeler, Orta Asya ülkeleri ile imzaladığı enerji anlaşmalarının yanında Irak savaşı ve Çin'in artan petrol tüketimi karşısında petrol fiyatlarının hızla yükselmeye başlaması Japonya'nın ilgisini Rus kaynaklarına kaydırmıştır. ${ }^{42}$ Diğer yandan o tarihte bir Rus özel şirketi olan YUKOS ile Çin devlet şirketinin Kremlin'in tüm uyarılarına rağmen kendi aralarında imzaladıkları boru hattı anlaşmasının imza törenine Başkan Putin katılmayarak iki tarafa karşı tepkisini göstermiştir. ${ }^{43}$ YUKOS'un Rus devleti tarafından kamulaştırılmasının ardından Çin, hızla Kremlin ile anlaşma yoluna gitmiş ve nihayet Eylül 2005'te bizzat Başkan Putin tarafindan ESPO'nun önce Çin'in Daqinq bölgesine ardından Pasifik sahiline ulaşacağı ilan edilmiştir. ${ }^{44} 2014$ yılında ikinci aşaması tamamlanınca Çin'e yılda 50 milyon petrol ${ }^{45}$ taşıması planlanan ESPO'nun Rusya için jeostratejik önemini Davidoviç şöyle açıklamaktadır:

Birincisi bu hat ülkenin [Rusya] en büyük pazarlarından birisi olan Asya Pasifik bölgesine çıkışıdır. İkincisi petrol boru hattının işletmeye alınması Rus petrol şirketlerinin petrol ihracatlarını çeşitlendirmesi, hem Avrupa'ya hem de Asya gönderebilmeleri için firsat yaratacaktır. Üçüncüsü Doğu Sibirya ve Uzak Doğu'ya kadar uzanan boru hattı bu bölgelerin sosyo-ekonomik gelişmeleri ile yeni hidrokarbon sahalarının geliştirilmesi için itici bir güç olacaktır. ${ }^{46}$

Rusya ve Çin arasındaki doğal gaz ilişkisine baktığımızda, Rusların Çin’e 2004 yılında batı ve doğu olmak üzere iki hat teklif ettiği görülmektedir. Batı hattı için planlanan 30 milyar metreküp kapasiteli Rusya’nın Altay bölgesinden Çin’in Sincan bölgesine giriş yapacak bir boru hattıdır. 40 milyar metreküp kapasiteli doğu hattının ise Sakhalin Adasından başlayarak Rusya'nın Vladivostok kentinin altından Kuzeydoğu Çin’e giriş yapması planlanmaktadır. ${ }^{47}$ Rusya'nın, Çin'in doğal gaz ihtiyaçlarına özel olarak önem vermesinin nedeni ise Çin'in gelecekte doğal gaz ihtiyacının Orta Asya kaynakları ile değil Rusya’nın kaynakları ile karşılanmasını istemesidir. Dolayısıyla bölgede üretici kimliğiyle yalnız olmayan Rusya Orta Asya ülkeleri ile bu konuda bir rekabet içindedir. Hattın inşa edileceğinin kesinleşmesinin ardından Başkan Putin'in 2006 yllında Pekin’i ziyareti sırasında Çin'in o dönemdeki başkanı Jintao ile enerji alanında işbirliğini de içeren ortak bir bildir-

42 Joseph Ferguson, Japanese-Russian Relations 1997-2007, Routledge, 2008, s.111-4, Marcin Kaczmarski, "An Asian Alternative? Russia's Challenges of Making Asia an Alternative to Relations with the West", Centre for Eastern Studies, Varşova, Haziran 2008, s.49.

43 Metallinou Spyridoula-Amalia, "Energy Security: The Russian Trans-Siberian Pipeline and the Sino-Japanese Courtship", Hydra Papers, Eylül 2006, s.3 http://nltest.webege.com/idis/EN/ Educational_programs/hydra_papers_en.htm (Erişim Tarihi 02 Mart 2014).

44 Cindy Hurst, "China's Global Quest for Energy LCDR", LAGS, Energy Security, Ocak 2007, s.5 http://www.iags.org/chinasquest0107.pdf (Erişim Tarihi 03 Mayıs 2013).

45 "Russia-China Oil Pipeline Opens", BBC News, 2 Ocak 2011, http://www.bbc.co.uk/news/ world-asia-pacific-12103865 (Erişim Tarihi 03 Mayıs 2013).

46 Davidovic, "China's Energy Policy", s.29.

47 Sevastyanov, "Russia and Northeast Asia, s.46. 
ge yayınlamışlardır. ${ }^{48}$ Bu bildirgenin itici gücü ile birlikte Moskova ve Pekin 2008 yılında Batı ve Doğu olmak üzere inşa edilecek olan doğal gaz boru hatları üzerinde anlaştıklarını açıklamışlardır. ${ }^{49}$

Sonrasında Aralık 2009'da Rusya'nın Gazprom Export şirketi ile Çin'in CNPC şirketi arasında doğal gaz tedarikinin nasıl olacağına dair temel bir anlaşma imzalanmıştır. Eylül 2010'da genel prensipleri belirleyen ön anlaşmalar dâhil olmak üzere ilgili tüm anlaşmaların imzalanmış olmasına rağmen Çin’in doğal gaz fiyatının daha düşük olması konusundaki ısrarı nedeniyle nihai anlaşma imzalanmamışır. ${ }^{50}$ Ancak Rusya ve Çin, Çin Devlet Başkanı Jinping'in 2013 Mart'ında Moskova'yı ziyareti sırasında doğal gaz alanındaki son anlaşmada mutabık kalmışlardır. Gazprom tarafının yaptığı açıklamaya göre Rusya ve Çin arasındaki anlaşma 30 yıllık bir anlaşmadır ki bu anlaşma tam da Rusya’nın Avrupa pazarındaki fiyat itirazlarının yükseldiği bir zamanda gerçekleşmiştir. İlk aşamada 2018 tarihinde yılda 38 milyar metreküp ile başlayacak olan doğal gaz ticaretinin gelecekte 60 milyar metreküpe çıması beklenmektedir. Bu miktar, Rusya’nın Avrupa pazarı için inşa etmeye başladığ 63 milyar metreküp kapasiteli Güney Akım hattının kapasitesine denk bir miktardır. ${ }^{51}$ Başkan Jinping' in Moskova ziyareti sırasında doğal gaz anlaşmasının yanı sıra Rus petrol şirketi Rosneft'de Çin'e gerçekleştirdiği petrol ihracatının iki katına çıkması (31 milyon ton) konusunda bir anlaşmaya varmışır. ${ }^{52}$ Böylelikle Rusya'nın Çin pazarına giriş yapan bir doğal gaz boru hattı inşa etmesiyle Rusya iki avantaj elde etmiştir. İleride Çin'in Rusya’ya olan bağımlllı̆̆ı artabilecek ve Rusya'nın uzak doğu bölgeleri gelişme firsatı bulacaktır. İkinci olarak da Rusya tek yönlü doğal gaz ihracat yolu yerine artık Batı ve Doğu olmak üzere çift yönlü bir ticaret hattına sahip olacaktır

\section{Japonya}

Kuzey Doğu Asya'daki jeopolitik durum siyasi, ekonomik ve askeri açıdan, bir yandan Çin'in büyüyen ekonomisi, Kuzey Kore'nin silahlanması, Japonya ve Güney Kore'nin ekonomisinin enerji bağımlılıkları ve son olarak da Çin-Rus stratejik işbirliğgi nedeniyle dinamik motifler sergilemektedir. Bu bağlamda Rusya ve Japonya arasındaki yeni yakınlaşma da dikkate değerdir. ${ }^{53}$ Soğuk Savaş ortamında iki ülke ilişkileri gergin bir çizgide devam

48 Sergey Sevastyanov, “The More Assertive and Pragmatic New Energy Policy in Putin's Russia: Security Implications for Northeast Asia”, East Asia, 25, 28 Mart 2008, s.46.

49 Ibid, s.46, Mark A. Smith, "The Russo-Chinese Energy Relationship”, The Defense Academy of the United Kingdom, 10/14, Ekim 2010, s.6.

50 "Price for Russian Gas Deliveries to China to be Set by July 2011-Sechin", RIA Novosti, 21 Eylül 2010, http://en.rian.ru/world/20100921/160662039.html (Erişim Tarihi 18 Mayıs 2013).

51 Erica S. Downs, “Money Talks: China-Russia Energy Relations After Xi Jinping's Visit to Moscow", Brookings, 1 Nisan 2013, http://www.brookings.edu/blogs/up-front/ posts/2013/04/01-china-russia-energy-relations-downs\# (Erişim Tarihi 29 Ocak 2014).

52 James Marson, "Russia and China in Major Natural-Gas Supply Contract", The Wall Street Journal, 22 Mart 2013, http://online.wsj.com/article/SB1000142412788732455780457837651 0628682312.html (Erişim Tarihi 18 Mayıs 2013).

53 Joseph P. Ferguson, “Nordpolitik: Japan's New Russian Policy”, Journal of Public and International Affairs, Cilt 9, Bahar 1998, s.25. 
etmiş olsa da 1998 yılında dönemin Rusya Devlet Başkanı Yeltsin ve Japon Başbakanı Ryutora'nın Rusya'nın Sakhalin adasındaki Japon azınlığın yaşadığı Yuzhni-Sakhalinsk şehrinde Japon konsolosluğunun aç1lış töreninde bir araya gelmeleri ilişkilerin normalleşmesinin başlangicı olmuştur. ${ }^{54}$

Enerji kaynakları açısından ithalata bağımlı olan Japon ekonomisi, daha önce 1973 yılında petrol fiyatlarının yükselmesinin yol açtığı zarar nedeniyle dersler çıkartmış ve buna göre önlemler almaya çalışıştır. Bir ada ülke olması ve sadece deniz ulaşımı ile enerji kaynaklarına erişebilmesi ülkenin önemli bir zaafıdır. 1973 krizine rağmen ülke, Orta Doğu enerji kaynaklarına olan bağımlllı̆̆ını yüzde 80'in altına düşürememiştir. ${ }^{55}$ Enerji arzı çeşitliliği yaratabilmek adına Japon enerji şirketleri Sakhalin-1 ve Sakhalin-2 projelerinde olduğu gibi Rusya'nın uzak doğu bölgelerine yatırım yapmak üzere Japon hükümetlerince teşvik edilmiştir. Japon şirketleri üretecekleri doğal gazı boru hattı ya da LNG ile kendi adalarına ulaştırabilmek için uzun yıllardır yollar aramakta ve bu bölgede Çin şirketleri ile rekabet etmektedir.

Vladimir Putin'in Başkanlığa seçilmesi ile birlikte 2000’lerin ilk yarısında Rus ve Japon ilişkilerinde gözle görülür bir ilerleme kaydedilmiştir ${ }^{56}$ ve Japon enerji şirketleri Rusya’da yatırım yapmaya başlamıştır. Örneğin; Sakhalin-1 projesinde Japon şirketleri SODECO'nun yüzde 30 ve Sakhalin-2 projesinde Mitsui'nin yüzde 12,5 ve Mitsubishi'nin yüzde 10 oranında hisseleri bulunmaktadır. Sakhalin projelerine ek olarak Japonlar ESPO projesi ile de ilgilendiklerini beyan etmişlerdir. Mart 2008'de Japon hükümeti ile Rusya'nın en büyük petrol şirketi Rosneft arasında enerji alanında işbirliğini temel alan karşıllklı iyi niyet anlaşması imzalanmıştır. ${ }^{57}$

31 Mayıs 2006'da Japon Ekonomi, Ticaret ve Sanayi Bakanlı̆̆’'nca açılanan Japonya’nın Yeni Ulusal Enerji Strateji Belgesi Japonya'nın büyüyen küresel enerji pazarındaki yeri açısından endişelerini yansıtmaktadır. Belgede Asya ekonomilerinin her geçen yıl daha artan miktarlarda Orta Doğu kaynaklarına, bir başka deyişle Hürmüz Boğazı'na bağımlı hale geleceği öngörülmektedir. ${ }^{58} \mathrm{Bu}$ nedenle Japonya'nın özellikle Fukişima felaketinden sonra enerji bağımlllı̆̆ konusunu gözden geçirmesi gerekmektedir. Mart 2011'deki depremden itibaren Japonya'nın LNG ithalatı ve ödemelerinin giderek arttığ1 görülmektedir. Japonya’nın 2010 y1lında almı̧ olduğu 76 milyar metreküp gaz, 2011 yılında 86 milyar metreküpe yükselmiş ve ödenen fatura da 39,5 milyar dolardan 60

54 Ibid., s.26-31.

55 Ibid., s.31-33.

56 Susumi Yoshida, "Energy Cooperation and Japan-Russian Relations", s.31, http://www.sei.irk. ru/aec/proc2006/4.pdf (Erişim Tarihi 18 Mayıs 2013).

57 Svetlana Vassiliouk, "Japanese-Russian Energy Cooperation: Problems and Perspectives", Dünya Medeniyetleri Forumunda yapılan sunumdur, Rodos, Yunanistan, 9-13 Ekim 2008, IEEJ Newsletter, No 8, 19 Kasım 2012, s.4-7 http://eneken.ieej.or.jp/en/jeb/1211.pdf (Erişim Tarihi 18 Mayis 2013).

58 Jan-Hein Chrisstoffels, "Getting to Grips Again with Dependency; Japan's Energy Strategy", Clingendael International Energy Programme, Ağustos 2007, s.1. 
milyar dolara yükselmiştir. ${ }^{59}$ Japon enerji analizcisi Hiroshi Hashimot LNG pazarı için orta ve uzun vadede şu öngörüde bulunmaktadır:

Bugünden 2015'e mevcut pazarlarda LNG talebinin düzenli olarak artarken Güneydoğu Asya ülkelerinden bir kaçı yeni LNG ithalatçıları olarak ortaya çıkacaklar. Ancak, arz tarafinda Batı Avusturalya, Angola ve Cezayir olmak üzere sadece az sayıda yeni projeler bulunmaktadır. Bu bağlamda, Putin'in yeni döneminde Japon-Rus ilişkilerimin gelişmesi için özel bir özenin gösterilmesi gerekmektedir. ${ }^{60}$

Günümüzde Japonya ve Rusya arasında LNG terminalleri inşası için bir takım projeler üzerinde çalışmalar yapılmaktadır. Bunlar arasında Gazprom’un fizibilite çalışmaları yapmaya başladığı Vladivostok kentinde inşa edilmesi düşünülen LNG terminali göze çarpmaktadır. Ĕger iki ülke Vladivostok üzerinden gelecek LNG üzerinde mutabık kalırlarsa, gaz önce Sakhalin-1 sonra Sakhalin-2 ve Sakhalin-3 projelerinden gazı aldıktan sonra boru hattıyla Vladivostok'a ulaşacak ve oradan da tankerlerle hemen karşıdaki Japonya'ya ulaştırılacaktır. ${ }^{61} \mathrm{Bu}$ aşamada Japon-Rus enerji ilişkileri açısından Asya $\mathrm{Pa}-$ sifik Ekonomik İşbirliği Teşkilatı-APEC-2012 zirvesi bir dönüm noktasıdır. Rusya’nın Vladivostok kentinde düzenlenen zirve sırasında Rusya ve Japonya 8 Eylül'de Çin ve iki Kore'nin gaz alım ihtimallerini de erteleyebilecek olan 7 milyar dolar değerinde bir LNG terminali yapmak için anlaşmaya vardıklarını açıklamışlardır. Günümüzde Rusya’nın Sakhalin adasında Gazprom ve Shell şirketlerinin birlikte işlettikleri yıllık 10 milyon ton taşıma kapasiteli bir LNG terminali bulunmaktadır. Vladivostok'ta inşa edilmesi planlanan yeni terminalin ilkinin iki katı kapasitede olması hedeflenmektedir. Rus-Japon LNG anlaşmasının, APEC zirvesi sırasında henüz Rusya ile doğal gaz konusunda nihai anlaşmayı imzalamamış olan Çin tarafında büyük bir hayal kırkılı̆̆ı yarattı̆̆ı muhakkaktır. Rus Enerji Bakanı Aleksander Novak, Çin’in anlaşma müzakerelerini uzattığı bir dönemde gelen LNG hamlesi için "Çin isterse Vladivostok'taki yeni LNG terminalinden gaz alabilir” diyerek Çin tarafına Rusya’nın mesajını iletmiştir. ${ }^{62}$ Böylelikle Japonya ile LNG pazarını genişletme fırsatı bulan Kremlin, müzakerelerden kaçınan Çin’i doğal gaz fiyatı konusunda masaya oturtmayı başarmıştır.

\section{Kuzey ve Güney Kore}

Kuzey ve Güney Kore arasındaki sorunlar göz önüne alındığında, sorunun yıllar içerisinde çok yönlü ve karmaşık bir güvenlik mücadelesine dönüştüğü gözlemlenmektedir.

59 Japan Energy Brief, No.18, Mart 2012, s.4-5, http://eneken.ieej.or.jp/en/jeb/1203.pdf (Erişim Tarihi 18 Mayss 2013).

60 Ibid., s.6-7.

61 IEEJ Newsletter, No 13, 15 Nisan 2013, s.9, http://eneken.ieej.or.jp/en/jeb/1304.pdf (Erişim Tarihi 18 Mayss 2013).

62 Katya Golubkova ve Denis Pinchuk, "Russia, Japan back LNG; Could Delay Export Pipelines", Reuters, 8 Eylül 2012, http://www.reuters.com/article/2012/09/08/us-russia-lng-asiaidUSBRE88705R20120908 (Erişim Tarihi 18 Mayıs 2013). 
Kuzey ve Güney Kore ekonomilerinin ihtiyaç duydukları enerji taleplerine bakıldığında hem gelir düzeyleri nedeniyle oluşan bir farklılık hem de uluslararası pazarlara ulaşım açısından farklılıklar bulunmaktadır. ${ }^{63}$ Başkan Putin'in de destek verdiği, Rusya’dan başlayarak Kuzey Kore'ye ve oradan da Güney Kore topraklarına ulaşarak iki Kore arasında birleşmeyle sonuçlanabilecek bir girişim olan bir doğal gaz boru hattının inşası projesi öncelikle Kremlin tarafindan ortaya atışmı̧̧ır. Rusya bu amaç doğrultusunda iki Kore ile uzun dönemli üçlü ekonomik işbirliğini öngören adımlar atmaktadır. Örneğin; 2013 yılının başında Rus Dışişleri Bakanı Lavrov, "Rusya, Kuzey ve Güney Kore arasında doğal gaz arzı gibi projeler hakkında üst-düzeyde fikir alış verişini desteklemektedir" beyanında bulunmuştur. ${ }^{64}$ Diğer yandan, Rusya ve Güney Kore esasen enerji işbirliği konusunu 1990'lardan beri görüşmeler yapmaktadırlar. Rusya’nın Kovykta sahasında 1980'lerin sonunda dev bir doğal gaz rezervi bulunmasının ardından Moskova, buradan çıkacak doğal gazı Çin ve oradan da Güney Kore'ye ulaştırmanın yollarını aramaya başlamı̧ fakat bu proje gerçekleştirilememiştir. ${ }^{65}$

Güney Kore kendi kaynakları olmamasına rağmen 2011'i dünyanın en büyük on birinci enerji tüketicisi olarak tamamlamıştır ve ekonomisinin ihtiyacı olan enerji kaynakları açısından neredeyse tamamen dış kaynaklara muhtaç durumdadır. Özellikle petrol alanında ülke tamamen dışarıdan kaynak ithal etmek zorundadır. Dolayısıyla Güney Kore dünyanın önde gelen petrol ithalatç1larından birisidir ve kaynak ihtiyacının yaklaşı yüzde 80'inini Orta Doğu'dan sağlamaktadır. ${ }^{66}$ Y ine 2011 yılında dünyada en fazla LNG ithalatı yapan ikinci ülke, kömür ithalatında üç ve petrol ithalatında da beşinci ülkedir. Güney Kore'ye enerji kaynağı ulaştıran herhangi bir doğalgaz ya da petrol boru hattı yoktur ve tamamen deniz taşımacilığ ile limanlarına gelecek LNG ve petrol tankerlerine bağımlıdır. ${ }^{67}$

24 Ağustos 2011 tarihinde Rusya’nın üçüncü Devlet Başkanı Dmitri Medvedev ve önceki Kuzey Kore lideri Kim Jong-il, Rusya’nın doğu Sibirya kentlerinden birisinde buluşarak kritik bir zirve gerçekleştirmişlerdir. Zirve sırasında eski Kuzey Koreli lider Jong-il, Rusya Devlet Başkanı ile kendi ülkesinden geçtikten sonra Güney Kore topraklarına girecek olan Trans-Korea doğal gaz boru hattı projesi konusunda anlaştığını dünyaya açıllamıştır. ${ }^{6}$ Hemen ardından Kasım 2011 tarihinde ise bu kez Güney Kore Devlet

63 Kent E. Calder, “Korea's Energy Insecurities: Comparatives and Regional Perspectives”, Korea Economic Institute, Special Series: 3, 2005, s.1-3.

64 "Russia Says Ready For Trilateral Economic Cooperation With Koreas", Xinhuanet, 23 Ocak 2013, http://news.xinhuanet.com/english/world/2013-01/23/c_132123371.htm (Erişim Tarihi 18 Mayis 2013).

65 Se Hyun Ahn ve Micheal J.Jones, "Northeast Asia's Kovykta Conundrum: A Decade of Promise and Peril", Asia Policy, No 5, Ocak 2008, s.105-140.

66 George A. Hurchinson, “Addressing South Korea's Greatest Strategic Vulnerability: options For Decreasing Energy Dependency", International Journal of Korean Studies, Cilt XIII, No 1, Bahar-Yaz, 2009, s.107.

67 EIA - Güney Kore, 17 Ocak 2013, s.1, http://www.eia.gov/countries/analysisbriefs/South_ Korea/south_korea.pdf (Erişim Tarihi 18 Mayıs 2013).

68 "North Korea Agrees Gas Pipelines Deal and Return to NuclearTalks", RIA Novosti,24 Ağustos 2011, http://en.rian.ru/world/20110824/166106669.html (Erişim Tarihi 24 Mayıs 2013). 
Başkanı Myung-bak ve Başkan Medvedev'in Rusya'nın St. Petersburg kentinde imzaladıkları çeşitli anlaşmalarla, üç ülkeye de ekonomik çıkar sağlayacak olan doğal gaz boru hattı projesini onaylanmışlardır. ${ }^{69}$ Bunun ardından 2012 yılının sonuna doğru yapılan müzakerelerde Kuzey Kore'nin yüksek geçiş ücreti talebi bir tıkanmaya neden olmuştur. Güney Koreli kaynaklara göre Kuzey Koreli yetkililer normalden üç katı fazla geçiş ücreti talep etmektedirler. ${ }^{70}$ Boru hattının inşası sürecindeki tıkanmaya rağmen Rusya ve Güney Kore ticaret bağlamında Kuzey Kore ile ilgili olumlu adımlar atmışlardır. Bu çerçevede Başkan Putin'in 2013 Kasım ayında yeni Güney Kore lideri Park Geun-hye ile Seul'de gerçekleştirdiği zirvede önemli kararlar alınmıştır. Bunlardan en önemlileri Rusya'nın $\mathrm{Ku}-$ zey Kore'nin Rajin limanın geliştirilmesi ve hemen yakındaki Rusya sınırları dâhilindeki Hasan'a tren yolu bağlantısının gerçekleştirilmesi projeleridir. Güney Kore liderinin de zirvede projeye destek vermesi üzerine her ne kadar Trans-Kore doğalgaz boru hattı konusunda yeni bir anlaşma imzalanamasa da en azından Seul'ün Rusya'dan LNG alması konusunda bir seri işbirliği anlaşması imzalanmıştır. ${ }^{71}$

Bütün bunların 1şığında Kremlin, Trans-Kore boru hattı projesine o kadar inanmıştır ki, boru hattının finansmanını bizzat Rusya'nın sağlayabileceğini dahi ilan etmiştir. Kuzey Kore'nin nükleer projelerine hem Rusya hem de Güney Kore karşı çıkmalarına rağmen, iki Kore'nin de enerji konusundaki ihtiyaçları nedeniyle Rusya'nın enerji projelerinde aynı masaya oturabilmektedirler. Diğer yandan Trans-Kore boru hattı projesi de Rusya'nın Sibirya kaynaklarını kendisine çekecek bir başka proje olduğundan Çin tarafından kaygıyla karşılanmıştır. Ve bu projenin de Çin’i doğal gaz anlaşması için provoke etme amacı taşıdığ 1 iddia edilmiştir. ${ }^{72}$

\section{Sonuç}

Rusya Federasyonu'nun başından beri Rusya'nın ekonomisinin atar damarı olan enerji politikalarını dış politikasıyla uyumlu hale getirmeye çalıştığı görülmektedir. Rusya'nın günümüzde en önemli gelir kaynağı olan Avrupa enerji pazarı SSCB zamanında ve $\mathrm{Ku}$ zey Akım gibi daha sonra inşa edilmiş hatlar ile oldukça sıkı bağlarla Rus ekonomisinin ana eksenini oluşturmaktadır. Buna ilave olarak Rusya'nın gazını Karadeniz üzerinden Avrupa pazarına taşıyacak yeni bir boru hattının inşası da başlamış durumdadır. Ancak tek bir pazara Rus ekonomisinin bu kadar bağımlı olması aynı zamanda son derece riskli

69 "South Korea, Russia Agree to Push Gas Pipeline Through North Korea", The Chosunilbo, 3 Kasim 2011, http://english.chosun.com/site/data/html_dir/2011/11/03/2011110300708.html (Erişim Tarihi 27 Mayıs 2013).

70 “N. Korea Demands 'Rip-off Free' for Gas Pipeline”, The Chosunilbo, 4 Ekim 2012, http:// english.chosun.com/site/data/html_dir/2012/10/04/2012100401124.html (Erişim Tarihi 1 Şubat 2014).

71 Chong Jae-Soon, "S.Korea to Participate in Russan-led Rail, Port Development Project in North Korea”, Yonhap News, 13 Kasim 2013, http://english.yonhapnews.co.kr/national/2013/ 11/12/10/0301000000AEN20131112007053315F.html (Erişim Tarihi 1 Şubat 2014).

72 Beom-Shik Shin, "Russia's 'Return' to Asia: How Should South Korrea Respond?”, EAU Issue Briefing No MASI, 30 Aralık 2011, s.1. 
bir durum oluşturmaktadır. Rusya için artık Kuzey Doğu Asya ülkeleri ve özellikle de Çin enerji pazarına sağlam bağlar kurmanın zamanı gelmiştir. 2013 yılı Şubat ayının ortasında Başkan Putin, Başkanlık Enerji Komisyonu toplantısında, Rusya'nın gaz pazarının hızla büyümesine rağmen küresel LNG pazarındaki yüzde 3,6 paydan duyduğu rahatsızlığ ve hoşnutsuzluğu belirtmiştir. Aynı toplantıda Başkan Putin; "Biz [Rusya] bu sektörü geliştirebilmek için gereken doğru koşulları yaratmalıyı" değerlendirmesini yaparak LNG sektörüne verdiği önemi bir kez daha dile getirmiştir. ${ }^{73}$ Başkan Putin'in bu açıklamaları yaptı̆̆1 günlerde ExxonMobil şirketi ile imzalanan anlaşmayla şirketin Rusya'nın Uzak Doğu'sunda yeni LNG projeleri için fizibilite çalışmaları yapmaya başladığı ilan edilmiştir. Rosneft' in başkanı İgor Sechin'in Kuzey Doğu Asya seyahati sırasında 16 Şubat tarihinde Güney Kore'de KOGAS şirketi ile, 17-19 Şubat tarihinde Çin'de CNPC, Sinopec ve CNOOC şirketleriyle çeşitli temaslarda bulunduğu ve son olarak 20 Şubat tarihinde Japonya da bir dizi temaslarda bulunduğu bildirilmiştir. ${ }^{74}$ Diğer yandan Çin'in artmakta olan enerji ithalatı ile Avrupa ekonomisinin ihtiyacı olan enerji ithalatı arasında çok büyük bir fark bulunmaktadır ve Çin uzun vadede Rusya için büyük bir enerji pazarı özelliği taşımaktadır.

Bölgenin en önemli enerji üreticisi konumundaki Rusya’nın oynayacağı kilit rol, artan enerji talebi nedeniyle Çin de Kuzey Doğu Asya bölgesinin enerji güvenliğine etki eden bir aktör olmasıyla neticelenecektir. ${ }^{75}$ Japonya ve iki Kore önemli enerji pazarları olmakla birlikte Kremlin açısından önemli olan Çin'in enerji pazarına mümkün olduğunca ulaşmaktır. Çin'in devasa petrol ve doğal gaz ihtiyacı için öncelikle Orta Asya devletlerine yönelmesi ve son on yıl içerisinde bu ülkelerdeki yatırımları aracilı̆ı ile kendi topraklarına ulaşan boru hatları inşa etmiş olması, Rusya'nın kaygılandı̆̆ı ve dikkatlice izlediği gelişmelerdir. Unutulmamalıdır ki, Rusya açısından Orta Asya kaynakları aynı zamanda Batıya gerçekleşen enerji ihracatı açısından da son derece önemlidir. Çin'in bu bölgedeki enerji işbirliği projeleri, Rusya dış enerji politikası açısından bir müşteri kaybı ya da kazancından ziyade Rusya'nın kaynak tedariki kapasitesinin yeniden tanımlanması anlamına gelmektedir. Bu nedenle Çin, Kremlin açısından hem rakip hem de müşteri durumundadır. Petrol konusunda ESPO boru hattı ile bir ilerleme kaydedilmiş olsa da Çin, doğal gaz konusunda Rusya'yı uzun zamandır pazarlık masasında tutmaktadır. Dolayısıyla özellikle son bir kaç yıldır Rusya'nın Japonya ve iki Kore ile izlediği enerji diplomasisi adeta Çin'in olumsuz tutumuna karşı bir alternatif plan olarak ortaya çıkmışır.

$\mathrm{Bu}$ bağlamda Rusyànın oluşturduğu Kuzey Doğu Asya enerji stratejisinde, Avrupa'da olduğu gibi sadece boru hatları yer almamakta, bu kez karşımıza LNG sektörü de çıkmaktadır. Bu nedenle Rusya'nın Çin'i ikna edene kadar Japonya ve iki Kore ile imzaladığı enerji anlaşmaları kendi başına Rus enerji stratejisi açısından etkili olsa da esas amaç doğal gaz boru hattının sonuçlanması ve fiyatlar konusunda Çin tarafının ikna

73 Rusya Devlet Başkanı, "Meeting of the Commission For Strategic Development of the Fuel and Energy Sector and Environmental Security”, 13 Şubat 2013, http://eng.state.kremlin.ru/ face/4994 (Erişim Tarihi 27 Mayıs 2013).

74 IEEJ Newsletter, No.13, s.9.

75 Sevastyanov, "Russia and Northeast Asia”, s.46. 
edilmesidir. Bu stratejinin meyvesi Çin devlet başkanı ve Rus devlet başkanının doğal gaz fiyatları konusunda anlaşması ve gazın pompalanmaya başlayacağı tarihin açıklanmasıyla alınmıştır. Önümüzdeki dönemde her ne kadar Çin, Kuzey Doğu Asya'da Rusya açısından öncelik arz etse de, özellikle Japonya, Rusya'nın ikinci önemli enerji pazar hedefi olarak belirmektedir. Bilhassa 2011 depreminden ve Fukuşima felaketinden sonra kapanan Japon nükleer reaktörleri Japon enerji ihtiyacını dramatik şekilde arttırmıştır. Dolayısıyla Vladivostok'ta inşa edilecek bir LNG santrali Çin'e rağmen önemini yitirmemiş, tam tersi Rus dış enerji politikasının önemli bir hedefi haline gelmiştir. Son olarak Rusya'nın Kuzey Doğu Asya hedefinde üçüncü sırada yer aldığını gördüğümüz Kuzey ve Güney Kore'ler dikkati çekmektedir. Kuzey Kore'de 2011'de yaşanan lider değişikliği sonrasında iktidara gelen yeni lider Kim Jong-un'un da babası gibi uluslararası toplumca sert biçimde eleştirilen bir diktatör olmasına rağmen Rusya'nın Trans-Kore boru hattı projesini ertelemesine yol açmamış, bilakis gerekli müzakerelere devam edilmiştir. Trans-Kore boru hattını Güney ve Kuzey Kore'yi birbirine yakınlaştıracak bir argüman olarak da kullanan Rus dış enerji politikası, boru hattında nihai sonuca imza atamasa da Kuzey Kore ile liman anlaşması ve Güney Kore ile de LNG anlaşması imzalamı̧şır. Sonuç olarak Çin, Japonya ve iki Kore ile yapılacak enerji ticaretinin Rusya'nın Uzak Doğu'sunda ekonomik bir canlanma yaratması beklenmekte ve yeni enerji rezervleri için yeni yatırım kaynaklarının ortaya çıkmasını sağlaması umulmaktadır. Burada da itici gücün Çin'in enerji talebi olacağ̣ düşünülmektedir. 


\section{Kaynakça}

“Energy Strategy 2030”, Russian-American Business, 3 Kasım 2009, http://russianamericanbusiness.org/web_CURRENT/articles/545/1/Energy-strategy-2030 (Erişim Tarihi 4 Nisan 2013)

“North Korea Agrees Gas Pipelines Deal and Return to Nuclear Talks”, RIA Novosti, 24 Ağustos 2011, http://en.rian.ru/world/20110824/166106669.html (Erişim Tarihi 24 Mayıs 2013)

“N. Korea Demands 'Rip-off Free' for Gas Pipeline”, The Chosunilbo, 4 Ekim 2012, http://english. chosun.com/site/data/html_dir/2012/10/04/2012100401124.html (Erişim Tarihi 1 Şubat 2014)

"Price for Russian Gas Deliveries to China to be Set by July 2011-Sechin”, RIA Novosti, 21 Eylül 2010, http://en.rian.ru/world/20100921/160662039.html (Erişim Tarihi 18 Mayıs 2013)

“Russia Adopted New Energy Strategy”, Barents Observer, 28 Ağustos 2009, http://www.barentsobserver.com/russia-adopted-new-energy-strategy.4625792-116320.html (Erişim Tarihi 4 Nisan 2013)

“Russia Becomes Leading Oil Producer, BP Says”, BBC News, 9 Haziran 2010, http://www.bbc. co.uk/news/10275183 (Erişim Tarihi 10 Mayıs 2013)

"Russia Says Ready For Trilateral Economic Cooperation With Koreas", Xinhuanet, 23 Ocak 2013, http://news.xinhuanet.com/english/world/2013-01/23/c_132123371.htm (Erişim Tarihi 18 Mayıs 2013)

“Russia-China Oil Pipeline Opens”, BBC News, 2 Ocak 2011, http://www.bbc.co.uk/news/worldasia-pacific-12103865 (Erişim Tarihi 03 Mayıs 2013)

"Russian Government to Approve Pipeline Construction Schedule in 2005”, Ria Novosti, 1 Aralik 2005, http://en.ria.ru/russia/20051201/42283689.html (Erişim Tarihi 29 Ocak 2014)

"South Korea, Russia Agree to Push Gas Pipeline Through North Korea”, The Chosunilbo, 3 Kasim 2011, http://english.chosun.com/site/data/html_dir/2011/11/03/2011110300708.html (Erişim Tarihi 27 Mayıs 2013)

Ahn, Se Hyun and Micheal J. Jones, "Northeast Asia's Kovykta Conundrum: A Decade of Promise and Peril”, Asia Policy, 5, Ocak 2008, 105-140.

Beck, Roland, Annette Kamps, and Elitza Mileva, "Long-Term Growth Prospects For the Russian Economy”, European Central Bank, Occasional Paper, No.58, Mart 2007.

BP Energy Outlook 2030, Ocak 2013.

Bush, Keith, "Russian Economic Survey”, US-Russia Business Council, Aralık 2008, https://www. usrbc.org/ (Erişim Tarihi 10 Mayıs 2013)

Calder, Kent E., "Korea's Energy Insecurities: Comparatives and Regional Perspectives", Korea Economic Institute, Special Series: 3, 2005.

Chrisstoffels, Jan-Hein, "Getting to Grips Again with Dependency; Japan's Energy Strategy", Clingendael International Energy Programme, Ağustos 2007.

Cooper, William H., "Russia's Economic Performance and Policies and Their Implications for the United States," CRS Report For Congress, Order Code RL34512, 30 May1s, 2008, http:// www.fas.org/sgp/crs/row/RL34512.pdf, (Erişim Tarihi 22 Nisan 2013)

Cukrowski, Jacek, "Russian Oil: The Role of the Sector in Russia's Economy", Post-Communist Economies, 16, 3, 2004, 285-296. 
Davidovic, Sonja, “China’s Energy Policy in the Geopolitical Context”, Celeste Wallender (der.), Geopolitics of Energy in Eurasia - MSFS 536, 2008, http://www.atlanticcommunity.org/ app/webroot/files/articlepdf/China\%5C's\%20Energy\%20Policy.pdf, (Erişim Tarihi 14 Nisan 2013)

Downs, Erica S., “Sino-Russian Energy Relations An Uncertain Courtship”, James Bellacqua, (der.), The Future of China-Russia Relations, The University Press of Kentucky, 2010, 146-56.

Downs, Erica S., "Money Talks: China-Russia Energy Relations After Xi Jinping's Visit to Moscow”, Brookings, 1 Nisan 2013, http://www.brookings.edu/blogs/up-front/posts/2013/04/01-china-russia-energy-relations-downs\# (Erişim Tarihi 29 Ocak 2014)

EIA - Çin, Kasım 2010, http://www.eia.doe.gov/cabs/China/pdf.pdf (Erişim Tarihi 14 Nisan 2013)

EIA - Güney Kore, 17 Ocak 2013, http://www.eia.gov/countries/analysisbriefs/South_Korea/ south_korea.pdf (Erişim Tarihi 18 Mayıs 2013)

Energy Strategy of Russia For The Period Up To 2030, http://www.energystrategy.ru/projects/ docs/ES-2030_(Eng).pdf (Erişim Tarihi 01 Nisan 2013)

Export of Russian Crude Oil for 2000-2012, Russian Federal Customs Service and the Federal State Statistics Service, http://www.cbr.ru/eng/statistics/print.aspx?file=credit_statistics/ crude_oil_e.htm\&pid=svs\&sid=vt1 (Erişim Tarihi 10 Mayıs 2013)

Exports of Russian Natural Gas For 2000-2012, Russian Federal Customs Service and the Federal State Statistics Service, http://www.cbr.ru/statistics/print.aspx?file=credit_statistics/gas. htm (Erişim Tarihi 10 Mayıs 2013)

Ferguson, Joseph, “Nordpolitik: Japan's New Russian Policy”, Journal of Public and International Affairs, 9, 1998, 24-45.

Ferguson, Joseph, Japanese-Russian Relations 1997-2007, Routledge, 2008.

Gaddy, Cliffer G. And Barry W. Ickes, "Resource Rents and the Russian Economy”, Eurasian Geography and Economics, 46, 8, 2005, 559-583.

Gavrilenkov, Evgeny, “Growth in Russia and Economic Diversification”, Tabata Shinichiro ve Akihiro Iwashita, (der.), Slavic Eurasia's Integration into the World Economy and Community, Slavic Eurasian Studies, No.2, Sapporo, Japonya, 2004, 93-121.

Golubkova, Katya and Deniz Pinchuk, "Russia, Japan Back LNG; Could Delay Export Pipelines", Reuters, 8 Eylül 2012, http://www.reuters.com/article/2012/09/08/us-russia-lng-asiaidUSBRE88705R20120908 (Erişim Tarihi 18 Mayıs 2013)

Higashi, Nabuyuki, "Natural Gas in China, Market Evolution and Strategy”, IEA, Working Paper Series, Haziran 2009.

Hill, Fiona, "Energy Empire: Oil, Gas and Russia’s Revival”, The Foreign Policy Centre, Eylül 2004.

Huasheng, Zhao, “Sino-Russian Relations 2009 to 2010: A Perspective From China”, Russian Analytical Digest, 73, 23 Şubat, 2010.

Hurchinson, George A., "Addressing South Korea’s Greatest Strategic Vulnerability: Options For Decreasing Energy Dependency”, International Journal of Korean Studies, 13, 1: 107-129 Vol.XIII, No.1, 2009,107-129.

Hurst, Cindy, “China's Global Quest for Energy LCDR”, IAGS, Energy Security, Ocak 2007 http://www.iags.org/chinasquest0107.pdf (Erişim Tarihi 03 Mayıs 2013) 
ULUSLARARASIILIŞKILER / INTERNATIONALRELATIONS

IEEJ Newsletter, No 13, 15 Nisan 2013, http://eneken.ieej.or.jp/en/jeb/1304.pdf (Erişim Tarihi 18 May1s 2013)

IEEJ Newsletter, No 8, 19 Kasım 2012, http://eneken.ieej.or.jp/en/jeb/1211.pdf (Erişim Tarihi 18 May1s 2013)

Itah, Shaichi, "Sino-Russian Energy Relations: True Friendship or Phony Partnership?”, Russian Analytical Digest, No.73, 23 Şubat 2010.

Itoh, S., V.I. Ivanov, and D. Zha, "Chapter VI: China, Japan and Russia: The Energy Nexus, in Conflict Prevention and Conflict Management in Northeast Asia, 2005, 121-139.

Jae-Soon, Chong, "S.Korea to Participate in Russan-led Rail, Port Development Project in North Korea”, Yonhap News, 13 Kasım 2013, http://english.yonhapnews.co.kr/national/2013/11/ 12/10/0301000000AEN20131112007053315F.html (Erişim Tarihi 1 Şubat 2014)

Japan Energy Brief, No.18, Mart 2012, http://eneken.ieej.or.jp/en/jeb/1203.pdf (Erişim Tarihi 18 May1s 2013)

Kacmarski, Marcin, "An Asian Alternative? Russia's Challenges of Making Asia an Alternative to Relations with the West", Centre for Eastern Studies, Warsaw, Haziran 2008.

Kremlin, http://eng.putin.kremlin.ru/bio (Erişim Tarihi 29 Ocak 2014)

Legvold, Robert, "Russia's Strategic Vision and the Role of the Energy", NBR Analysis, Russian Energy Policy and Strategy, 1, 2, 2008, 9-21.

Liu, Xuecheng, "China's Energy Security and Grand Strategy", The Stanley Foundation, Policy Analysis Brief, Eylül 2006.

Marson, James, "Russia and China in Major Natural-Gas Supply Contract", The Wall Street Journal, March 22, 2013, http://online.wsj.com/article/SB10001424127887324557804578376 510628682312.html (Erişim Tarihi 18 Mayıs 2013)

Nakano, Junzo, "Japan's Security and the Russian Far East, in Sibera and the Russian Far East in the 21st Century: Partners in the "Community of Asia," Akihiro Iwashita, (der.), Vol.1, Crossroads in Northeast Asia, 2005, 39-54.

Orban, Anita, Poweri Energy and the New Russian Imperialism, Praeger Security International Press, 2008.

Raotava, Jouko, “The Role of Oil Prices and the Real Exchange Rate in Russia's Economy”, BOFIT Discussions Papers, 3, 2002.

Rudnitsky, Jake, "Russia's 2012 Oil Output Rises to Post-Soviet Record Prices", Bloomberg, 1 Şubat 2013, http://www.bloomberg.com/news/2013-01-02/russia-s-2012-oil-output-rises-to-post-soviet-record-on-prices.html (Erişim Tarihi 3 Mart 2013)

Russian Federation: Liquefied Natural Gas Exports, 2009-2012, Russian Federal Customs Service and the Federal State Statistics Service, http://www.cbr.ru/eng/statistics/print. aspx?file=credit_statistics $/$ Liquefied-Gas_e.htm\&pid=svs\&sid=ITM_7686 (Erişim Tarihi 10 Mayıs 2013)

Rusya Devlet Başkanı, "Meeting of the Commission For Strategic Development of the Fuel and Energy Sector and Environmental Security, 13 Şubat 2013, http://eng.state.kremlin.ru/ face/4994 (Erişim Tarihi 27 Mayıs 2013)

Sevastianov, Sergey, "Russia and Northeast Asia Energy Security", Rouben Azizian ve Artyom Lukin, (der.,) From APEC 2011 to APEC 2012: American and Russian Perspectives on Asia-Pacific Seucirty and Cooperation, 2012, 46-55. 
Sevastianov, Sergey, "The More Assertive and Pragmatic New Energy Policy in Putin's Russia: Security Implications for Northeast Asia”, East Asia, 25, 28 Mart, 2008, 35-55.

Shevtsova, Lilia, "Post-Communist Russia: A Historic Opportunity Missed”, International Affairs, 83, 5, 2007, 891-912.

Shin, Beom-Shik, "Russia's 'Return' to Asia: How Should South Korea Respond?", EAU Issue Briefing, No.MASI, 30 Aralık 2011.

Smith, Mark A., “The Russo-Chinese Energy Relationship”, The Defense Academy of the United Kingdom, 10/14, Ekim 2010.

Spyridoula-Amalia, Metallinou, "Energy Security: The Russian Trans-Siberian Pipeline and the Sino-Japanese Courtship”, Eylül 2006, http://www.idis.gr/GR/Ekpaideutika/hydra_papers/metallinou_amalia-spyridoula.pdf] (Erişim Tarihi 03 Mayıs 2013)

Vassiliouk, Svetlana, “Japanese-Russian Energy Cooperation: Problems and Perspectives”, For Presentation at the World Civilizations Forum, Rhodes, Greece, Ekim 9-13, 2008.

Yoshida, Susumi, “Energy Cooperation and Japan-Russian Relations”, 31-33, 2006, http://www.sei. irk.ru/aec/proc2006/4.pdf (Erişim Tarihi 18 Mayıs 2013) 


\section{Summary}

Since the proclamation of the Russian Federation in 1991, Russia had pursued a foreign energy policy in a way of integrating its foreign policy and economy structure. When Vladimir Putin became Russian President in 2000, he has realized that the energy sector is the number one priority for the Russian future in terms of being a superpower again. Despite its vast hydrocarbon reserves, the Russian economy is vulnerable due to prices of both oil and natural gas. Some studies indicate that oil prices have a significant impact on GDP growth in Russia. Therefore Russia needs long-term gas contracts in order to guarantee a high income as well as establish functional LNG sector. For this reason, Russia first aimed to maintain the long-term European gas market for export and Central Asian countries for the import strategy. The European market has been captured by Russia through the way of former pipelines and the new North Stream and not to mention that South Stream is on the way. However for Russia to be dependent on European market is too risky and fusty strategy, now it is time to expand Russian energy ties with East Asia particularly China.

In terms of East Asia market strategy, there are three important countries for Russia that are China, Japan and Korea (North and South). There is no doubt that due to a high growth in its energy demand, China will remain a key factor in defining Northeast Asia energy security, while Russia, as the only important regional supplier of energy, is capable of playing a critical role in it. Furthermore Russia's priority to reach China by oil and natural gas pipelines as well as preventing China's more integration with the Central Asian countries. The other two actors that are Japan and Korea (North and South) are also significant markets in Russia but not as having priority as China. However, the Chinese negative attitude on delaying natural gas contracts forced Russia to play an energy card once more in the North East Asia region. For this reason Russia signed contracts with Koreans and Japanese in order to make pressure on Chinese decision makers for their future.

Despite the fact that Japan and two Koreas energy demand are significant for Russia, both countries are used by the Kremlin to reach goals towards Chinese energy needs. In addition to that both Japan and South Korea are industrialized states that are only looking to diversify their energy imports. Nevertheless China's energy demand is tremendously high and much more crucial for Russia. As a result, Russia constructed a triangle of Russia-Japan-Korea that aiming to convince China for the natural gas connection which could not succeeded more than a decade due to Chinese objection to the gas price and the emergence of the Central Asia option. Nonetheless, LNG contract with Japan and Trans-Korean pipeline projects finally promoted China to sign long-term gas and oil contract with Russia. In this study, it is aimed to explain current Russian foreign energy strategy towards China, Japan, and two Koreas and predict a solution for Russia's new East Asia market strategy. 